\title{
Russia's war with Ukraine is to acquire military industrial capability and human resources
}

\author{
Jokull Johannesson \\ School of Business and Law, University of Agdar \\ Norway \\ jokull.johannesson@uia.no
}

\begin{abstract}
The Russia-Ukraine war presents a serious challenge as to understanding of President Putin's geopolitical intentions. This article uses a resource dependence perspective to explain Russia's motives for invading Ukraine. The invasion is driven by Russia's resource gaps in military-industrial capacity and human resources, and the fact that these resource gaps could be substantially mitigated by control over Ukraine's resources. The findings suggest implications for further research, policy and international business developments.
\end{abstract}

Keywords: Russia, Ukraine, military industrial complex, human resources, war.

JEL Classification: H56, N4, N44, F5, F51

\section{INTRODUCTION}

Russian invasion of Ukraine is the most critical geopolitical crisis the world leaders are facing currently, according to the UK Foreign Minister statement to the Parliament: "The crisis in Ukraine is the most serious test of European security in the 21st century so far...” (Hague, 2014). President Vladimir Putin's annexation of Crimea and control of large swathes of the Donbas region has left world leaders perplexed as to his motives in Ukraine. The central question is why? And some scholars, including inter alia (Barbashin \& Thoburn, 2014) and (Snyder, 2014) explain these Russia's actions in the light of its neocolonial imperial ambitions, with particular interest being to President Putin's comments on the so-called 'Novorossiya':

II would like to remind you that what was called Novorossiya (New Russia) back in the tsarist days - Kharkov, Lugansk, Donetsk, Kherson, Nikolayev and Odessa - were not part of Ukraine back then. These territories were given to Ukraine in the 1920s by the Soviet government. Why? Who knows' (Putin, 2014).

Zbigniew Brzezinski noted that President Putin's attempt to establish a Euroasian Union “.... is nothing but a new name for the former Soviet Union, or for the former Czarist Empire” (Gardels, 2014). Other writers point to Russian ethno-nationalist ideas (Rutland, 2014); Putin's emotions and personal grievances with Western leaders (Larson \& Shevchenko, 2014); (Tsygankov, 2014), economic problems in Russia (Treisman, 2014), populist politicking (M. A. McFaul, 2014); West's fault (M. McFaul, Sestanovich, \& Mearsheimer, 2014); strategic denial of Ukraine to NATO (Mearsheimer, 2014), economic problems (Mankoff, 2014); regime preferences (Smith, 2015) and finally, simply Russia's traditional values and 
interests (Tsygankov, 2015). This paper provides a different perspective on the Russia-Ukraine conflict and I do not apologize for raising different issues that may frustrate even the most enduring reader. This paper contributes to the explanation of Russia's motives in Ukraine and, I consider the Ukraine's military industrial complex and human resources so important to Russia that the Russia's leaders are willing to wage war to acquire control over them. Regardless of the literature's explanations, understanding why Russia attacks Ukraine remains unclear for two principle reasons. First, scholars have not addressed Russia's underlying strategic resource gaps in terms of military industrial capability and human resources that are threats to Russia. Second, scholars have not addressed how Russian control over Ukraine might close these resource gaps. I address these shortcomings in the literature in two ways. Firstly, by identifying the strategic resource gaps that represent existential threats to Russia, secondly, by identifying how Ukraine's resources can close or mitigate Russia's resource gaps and secure Russia's survival, and I do this through the lens of the resource dependency theory which will be reviewed in the next section.

However, before proceeding to the theory, let us consider a parallel situation prior to the Second World War. Germany's booty after the invasion of Czechoslovakia was the addition of 3.5 million Sudeten Germans to their population, the Skoda munition works - the second most important arsenal in Europe was in their hands, the Czechoslovakia army with personnel and equipment of 35 divisions, and the total Czechoslovakian population of ten million toilers and soldiers were added to Germany's strength. This changed radically the strategic balance of power in Europe. Therefore, we have enough reasons to suppose that addition to Russia of the 13.5 million Russian-speaking Ukrainians, acquisition of Ukraine's huge military industrial complex along with its huge stockpiles of Soviet era weapons, a military of 1.3 million including reserves, and the overall population of around 42 million might potentially have a very similar effect in terms of changes in the strategic balance of power in Europe.

\section{THEORETICAL PERSPECTIVES \& METHODOLOGY}

Against this background, I use the lens of the resource dependency theory to provide an alternative explanation to Russia's foreign policy in Ukraine. The resource dependence theory has been used to explain interstate advantages and politics and has primarily an external focus. Resource dependency theory scholars stress the importance of resources: physical resources i.e., Sprout and Sprout, (1951), scarce and critical resources, (Beitz, 1979) resource quality as source of peace, natural resources in terms of their interstate war potential (Reuveny \& Barbieri, 2014), technological advantage in a specific field (Kogut, 1991) such as Ukraine's specialty in rocket science and technology. This article contributes to the advance of the research dependency paradigm by expanding its application to provide an alternative explanation of the RussiaUkraine war and provide the structure for addressing key questions about Russia's motives for the aggression against Ukraine, such as: What resource gaps does Russia have? What Ukrainian resources can close Russia's resource gaps? What resources may Russia seek to establish strategic denial of? Where in Ukraine are the resources located? Hence the location predicts the geographical areas of interest to Russia. What are the implications for policy and international business? The central premise of this paper argues that President Putin's invasion of Ukraine is motivated by Russian Federation's need for critical resources from Ukraine to close Russia's resource gaps and secure Russia's survival.

Hence, the following two hypotheses constitute the resource dependency theory explanation of the Russia-Ukraine war.

Hypothesis 1: Russia's gap in military industrial capability and human resources are a threat to Russia.

Hypothesis 2: Ukraine resources can fill or mitigate Russia's resource gaps in military industrial capability and human resources. 
The resource dependency theory approach entails an empirical investigation of the independent variables -resources to explain the Russian government actions as the dependent variable. The first criterion for selecting the independent variables was that they must be a threat to Russia and, second, Ukraine's resources can close or significantly mitigate Russia's resource gaps. A reconnoitre study suggested that the two most critical resource gap threats to Russia were in the military industrial complex and human resources. Hence these were selected for this analysis in this study. Noteworthy is that the critical resources are not limited to political and military power but also economic resources and money as noted by Ukraine's ExPresident, Kuchma (KUCHMA, 2014):

"...there is not only an ideology and the protection of Russian-speakers behind it [war in Ukraine], but also very big money is involved here -- there is no doubt about it."

In totality, the empirical emphasis of this article is: (1) identifying Russia's resource gaps that present threats to Russia; (2) identifying Ukraine's resources that can fill or significantly mitigate Russia's resource gaps; (3) examining Russian government actions in respect to the resource gap closure. While I propose that the resource dependency theory give a better explanation of Russia's actions in Ukraine than provided by the authors cited at the beginning of this article, the explanatory variable- resources may not be the only deterministic and there may be other valid explanatory variables. The key premise here is that resource gaps is the most important explanatory variable in the equation.

I theorize that Euromaidan revolution threatened Russia's control of Ukraine's resources and when Russia was faced with a plausible loss of the resources to the European Union, the Russian invasion was inevitable. An EU control of Ukraine's resources would deny them to Russia and when the resources are properly developed by EU finance and technology they would be a direct strategic threat to Russia. Hence Russian control of Ukraine's resources for its own use and strategic denial to the EU became the motive for the Russia's aggression towards Ukraine. The research setting and data sources are discussed next.

Research setting. The objective of this study is to explain why Russia attacks Ukraine. To achieve this objective the paper uses an explanatory qualitative case study methodology (Yin, 1981, p. 61), (P. Ghauri, 2004); (P. N. Ghauri \& Grønhaug, 2005, p. 196). Qualitative case studies have long history in the organizational and international relations literature (Allison, 1971; Pressman \& Wildavsky, 1973); (Ferrier, 2001); (Levy, 2008); (J.-W. Lee, Song, \& Kwak, 2014)) and all the studies cited in the introduction above are qualitative case studies building a narrative from the available qualitative empirical data. Hence, in developing my argument, I depart deductively from resource dependency theoretical proposition and use empirically grounded interpretation of the evidence related to Russia's resource gaps, give alternative explanations of these evidence in relations to Ukraine's resources and form a conclusion based on the explanation in most agreement with these evidence as suggested by (Yin, 1981). However, this approach has its critics (Bryman, Bresnen, Beardsworth, \& Keil, 1988, p. 81); (T. W. Lee, Mitchell, \& Sablynski, 1999) and (Bryman, 2004).

Data. As sources of evidence, I used documents and archival records from the public sphere which includes journal articles, media reports, websites, government data bases and publications. To establish validity, effort was made to triangulate the data by corroborating evidence from multiple sources of data on each phenomenon. The selection of evidence on the resource gap variables was based on two criteria: First, the resource gap variable must present a threat to Russia and second, Ukraine's resources must fill or significantly mitigate the resource gap. The next section reports the findings. 


\section{RUSSIA'S GAPS IN MILITARY INDUSTRIAL CAPABILITY AND HUMAN RESOURCES AND IN HOW FAR UKRAINE'S RESOURCES MITIGATE THEM}

The findings suggest that the Russian Federation has existential resource gaps in military-industrial capability and human resources.

Ukraine's military industrial complex. Prior to the war, Ukrainian firms produced more than 3000 components and complete armament systems for the Russian military. The components are critical to Russia's production of more than 200 Russian armament systems because, during the Soviet Union Ukraine was well known for its military industrial complex and critical components of that industry was, and is, located in Ukraine. Consequently the Russian Federation is still dependent on Ukrainian production of unique critical components that cannot be acquired elsewhere according to Dmitry Rogozin, Deputy Prime Minister and Chairman of the Military-Industrial Commission (Rogozin, 2013). This includes the RM-36 (NATO designation SS-18 Satan) intercontinental ballistic missiles (ICBM) designed by the Yuzhnoye Design Bureau and manufactured by the Yuzhmash industrial complex in Dnipropetrovsk. The SS-18 Satan is the world's most destructive intercontinental ballistic missile and is armed with 10 independently targetable $750 \mathrm{kt}$ nuclear bombs or one 20 megaton nuclear bomb. The SS-18 Satan is a true doomsday weapon and poses an existential threat to Russia's enemies. Moreover, it is the JSC Khartron, Kharkov that produces the guidance system for all SS-18 Satan ICBMs. In 2008, a Russo-Ukrainian treaty contracted Ukraine firms to provide life extension upgrades and maintenance to extend the life of the SS-18 Satan to 2040 (Simha, 2014). Additionally, Ukraine enterprises produce the guidance systems for the SS-25 mobile missile launchers and SS-19 silo based strategic missiles that are made in the Kharkov region of Ukraine. Notably, it was the Ukrainian Yuzhmash that designed the R-5M, the USSR' first nuclear ballistic missile. All tallied, critical Ukrainian components and their servicing constitute $80 \%$ of Russia's strategic missiles forces. Hence Russia has a strategic resource gap in missile technology and one can argue that without Ukraine's missile technology Russia's long-term status as the preeminent nuclear power is at risk. Consequently, closing this resource gap by acquiring control over Ukraine's missile industry is a survival issue for Russia.

Strategic missiles and components are not the only Ukrainian resources critical to Russia as all branches of the Russian military have critical components designed, made and/or serviced in Ukraine because by the late 1980s seventy five percent of Ukraine's industrial capacity was used to manufacture Soviet weapons and components (Lugar, 2005) and the Russian navy was mostly built in Ukraine. The Mykolaiv oblast in southern Ukraine was the Soviet Union's key ship building centre with its shipyards, ship- turbine and gearbox factories. The Mykolaiv shipyards built most of the Soviet, now Russian, navy's capital ships including its flagship, the aircraft carrier Admiral Kuznetsov that was launched in 1985 from Nikolayev South Shipyard on the Black Sea coast of Ukraine. Although the Russian navy has received some new locally built corvettes and frigates, the Russian industry simply cannot produce large warships. Hence, the Russian order of the Mistral ships from France. This situation is a critical resource gap for Russia and its ability to project power outside its immediate boarders (Committee, 2014; Tolip, 2007) and Russia can mitigate this resource gap, in naval technology, by taking control of the Ukrainian shipbuilding industry.

Moreover, the Russian air force uses mostly air-to-air missiles produced in Ukraine and, Russian fighters have auxiliary systems made in Ukraine, including the hydraulic system for Russia's newest fighter the Su-34. The Russian army transport aircraft and helicopters use Ukraine jet engines made in Antonov factory in Kyiv and Motor Sich factory in Zaporizhia. In 2015, President Poroshenko placed a ban on military exports to Russia which stopped the delivery of Progress D-18t engines used in the production of the Russian AN-140, the tactical airlift aircraft for the Russian Army. The Progress D18T engines are 
designed by the Ivchenko-Progress Design Bureau and are manufactured by Motor Sich factory in Zaporizhia, Ukraine (Jennings, 2015). The AN-70, medium military transport, was a joint Russian-Ukrainian venture and the Ukrainian sanction caused the cancellation of the project and, in the heavy military transport category, the production and upgrading of the An-124 heavy military airlifter came to a halt and, one half of the components of the AI222-25 engine manufactured by the ODK company near Moscow for the YaK130 trainer aircraft were made in Ukraine. In addition to missiles and aviation, much of Russia's tank inventory was built in the Kharkiv Locomotive Factory in northern Ukraine, including the T-90 tank (McLees \& Rumer, 2014; Sutyagin, Clarke, \& Eyal, 2014).

The Ukraine's military industrial complex was for strategic reasons located in the eastern and southern part of the country. After Ukraine's independence, much of the military industrial complexes were organized into one state owned enterprise called Ukroboronprom Ukrainian Defence Industry. Today this conglomerate employs more than 120,000 people, is made up of more than 130 defence and engineering organizations and has an export arm Ukrspecexport (Anderson, 2014). The Ukroboronprom conglomerate produces: armoured vehicles, artillery armament, automotive vehicles, engineering and special equipment, ship and marine equipment, aircraft engineering and repair, radar, radio communication and air defence systems, high precision armament and ammunitions. In addition to the state owned Ukroboronprom, Ukraine has a great private armament industry of size and importance similar to Ukroboronprom's (McLees \& Rumer, 2014). Also, Ukraine has many enterprises producing machinery and mills crucial to Russian's military and industry and, perhaps, the heavy fighting around the city of Kramatorsk was basically over the control of NKMZ industrial complex which produces mining equipment, steel mills, and other industrial equipment, mostly marketed to the Russian Federation and Kazakhstan. Also Engergomashspetsstal, the large engineering and machine building complex and one of the world's leading suppliers of pressure vessels for nuclear reactors, including submarine reactors, is located in Kramatorsk, Ukraine (EMSS, 2015; NKMZ, 2014).

The Russian control of Crimea added 13 Ukrainian defence companies to Russia's toll and 18 defence companies located in Luhansk and Donetsk are now in Russia's hands. Little evidence is in existence of what Russia has done with the defence companies in the Donbass but, one eyewitness accounts tells of a total evacuation to Russia of the manufacturing equipment of defence company manufacturing rifle magazines in Luhansk.

Ukraine's sanctions on Russia have limited but, not stopped, exports of defence components to Russia and to make up for the lost Ukrainian components, Russia has instituted an import substitution program but, claims of its success needs to be viewed with caution as building up a sophisticated defence industry takes decades, not months, as demonstrated by the Ukrainian TVZ-117 engine which powers many of Russia's helicopters. Russia instituted an import substitution program for helicopters and planned to use their own Klimov VK-2500 engine for all their helicopters but only 30 were available for import substitution in 2015 as the Russian production output of these engines was already earmarked for installation in the Kamov-50 and Kamov-52 attack helicopters. Noteworthy is the fact that the Kimov-2500 engine was designed and first manufactured by the Motor Sich company in Ukraine and is one of the world best turboshafts.

President Putin's ten-year plan for a massive rearmament of the Russian Federation military can not materialize due to critical resource gaps unless Kremlin gets control of Ukraine's valuable military industrial complex with its original and rare competence that the Russian Federation has not been able to duplicate. The military industrial complex requires large highly educated pool of human resources which will be analysed in the next section.

Human Resources. The Russian military industries have suffered a crisis in personnel because of lack of critical skills and the Russian demographic trends. The world's largest country had only a population of 
143.7 million in October 2014 and that is a decline of five million people since 1993 (FSSS, 2015a). The United Nations estimates that the Russian population will decline by 400,000 per year to 2020 and 6-700,000 per year thereafter until 2050 (United-Nations, 2015). So, if this trend is not reversed then the population may have declined to 125 million by 2050 like Japan's population in 2015. Moreover, the age structure of the population is a cause for concern as the Russian population is aging and only $21 \%$ of the population under 20 years of age. The largest age group is $40-60$ constituting $34 \%$ of the population, people older than 60 years of age are $19 \%$ and only $31 \%$ of the population is aged between $20-40$ years (FSSS, 2014b). The decline in population was momentary reversed in 2014 due to more births, immigration and the influx of 800,000 refugees from Ukraine (TASS, 2015a). The declining and aging population must be a great worry for President Putin and how is he going to produce the weapons he needs to defend this gigantic country against threats from all sides with ever diminishing and aging population? In the east, there are the 1.3 billion Chinese, to the south there are more than 1.2 billion Indians and central Asians and to the west is the 500 million plus EU. From the resource dependency theory perspective, the declining and ageing population is a strategic resource gap that poses an existential threat to Russia. Hence, it must be addressed by President Putin and the answer is most likely an acquisition of large part of Ukraine as its population of 45 million bridges the Russian Federation's resource gap in human resources. Furthermore, the strategic denial of the human resources to the EU is of lesser importance to Russia but Ukraine's low wages and well-educated workforce has the potential for the EU to have on its borders a low-cost production centre rivalling China's labour costs and India's service industry.

\section{CONCLUSION, IMPLICATIONS AND FUTURE RESEARCH DIRECTIONS}

The empirical findings support the two hypotheses based on the resource dependency theory approach and give legitimacy to the theory's explanatory ability. In a nutshell, the Russian Federation has critical resource gaps in military-industrial capability and human resources. Furthermore, Ukraine's resources fill or significantly mitigate Russia's resource gaps. Consequently, the Russian government actions in Crimea and Donbass corresponded to the theory's suggestion that a government takes actions to secure resources critical to its existence. The domino effect of the scenarios discussed above is that Russia is likely to attempt to gain control of more geographical areas where Ukrainian resources are located. The geographical areas likely to fall under Russian dominance are the southern part of Ukraine and the east of the river Dnieper which have 2/3 of the Ukrainian population (Ukrstat, 2014). Furthermore the Ukrainian population is relatively young, speaks Russian as first or second language and almost $70 \%$ of the Ukrainians attended one of the 800 higher education institutions and 200 full fledge universities in Ukraine (Tatsenko, 2014). The addition of the 29 million Ukrainians, from these areas of Ukraine, to Russia's population pool could make or break the viability of the Russian Federation and solve its biggest resource problem: the lack of human resources with the right amount of wide competence. The specific areas of interest to Russia are the Ukraine districts east of the river Dnieper because of the human resources and the location of main industrial complexes. The Black Sea coastal districts of interest to Russia are Crimea for its ports and the Mykolaiv and Odessa districts for their shipbuilding industries. Also, the capital Kiev is of interest to Russia because of the scientific institutions and industrial capacity located there.

The immediate outcome of Russia's resources gaps was the annexation of Crimea and the war in the Donbass region where much of Ukraine's resources are located. The intermediate outcome is perhaps the ongoing Russian New Generation Warfare in Ukraine (Berzins, 2014) and ultimately Russia may attempt to get effective control of the resource rich areas mentioned above as the specific areas of interest to Russia.

This article is perhaps the first study to investigate the Russia-Ukraine war from the resource dependency theory perspective with an emphasis on Ukraine's military industrial complex and human resources and 
provides a fresh insight into Russia's aggression in Ukraine. The key premise that the aggression is motivated by the Russia's gap in critical resources and that control of Ukraine bridges this gap receives little attention in the literature and public media. Therefore, we may need to refocus our thinking about the Russia-Ukraine war and perhaps wars in general and shift from a geopolitical focus to a more business oriented perspective and consider wars as extension of business. In reflection on this conclusion and President Kuchma's statement cited above. Perhaps war is business!

The conclusions have implications both for theory and business. The theoretical contribution of this study shows that the resource dependency theory can contribute insight into the underlying causes of the RussiaUkraine war and shed light on the aggressor's strategic intent and actions. This finding suggests increased influence of resource scarcity on government policy in international relations, which is characterized by conflicts and wars fought over fundamental resources such as human resources and critical industrial capacity.

The implications for future research are that the resource dependency theory can be used for the analysis of other conflicts such as the Syria war and China's actions in Asia. A resource dependency theory analysis of plausible Russia-China and Russia-EU conflicts appears to be particularly fruitful. Especially if one considers the plausibility of a merger of these combinations rather than a war between them.

The implications for the Ukraine government are that it needs to make it clear that resources under threat will be denied to Russia by defence, evacuation or destruction.

The implications for international business are different. Ukraine's resources are important to international businesses too. Companies could develop the well-educated workforce into a relatively low-cost manufacturing and technology hub located next door to the EU. Finally, the Ukrainian military-industrial complex is a treasure to international arms businesses marketing to an ever more turbulent world. Consequently, foreign defence businesses have a tremendous opportunity to acquire key resources in Ukraine at a time when low market value and the low exchange rate make the resources a real bargain.

The application of the resource dependency theory to the explanation of the motives for armed conflict, in this paper, lays down a concrete basis for further research into the motives for military conflicts in other geographical areas. Particularly, the theory could be used to investigate Russia's motives for participating in the Syrian war.

\section{ACKNOWLEDGEMENT}

The author is thankful to the anonymous reviews providing very constructive reviews and suggestions which were incorporated into the final version and improved this paper. Moreover, the author thanks colleagues and friends who reviewed the drafts of the paper for the same.

\section{REFERENCES}

Allison, G. T. (1971). Essence of. Decision: Explaining the Cuban Missile'Crisis, Boston: Little, Brown.

Anderson, G. (2014). Ukroboronprom announces new Director General. IHS Jane's Defence Industry.

Barbashin, A., \& Thoburn, H. (2014). Putin's brain: Alexander Dugin and the philosophy behind Putin's invasion of Crimea. Foreign Affairs, 31.

Beitz, C. R. (1979). Political theory and international relations (Vol. 13): Cambridge Univ Press.

Berzins, J. (2014). Russia's New Generation Warfare in Ukraine: Implications for Latvian Defense Policy. Policy Paper 2. Retrieved from http://www.naa.mil.lv/ /media/NAA/AZPC/Publikacijas/PP\%2002-2014.ashx.

Bryman, A. (2004). Qualitative research on leadership: A critical but appreciative review. The Leadership Quarterly, 15(6), 729-769.

Bryman, A., Bresnen, M., Beardsworth, A., \& Keil, T. (1988). Qualitative research and the study of leadership. Human relations, 41(1), 13-29. 
Committee, D. ( 2014). Defence-Committee - Third Report: Towards the next Defence and Security Review: Part Two-NATO. Retrieved from: http://www.publications.parliament.uk/pa/cm201415/cmselect/cmdfence/358/35802.htm

EMSS. (2015). EMSS Energomashspetsstal. Retrieved from http://emss.ua/en/

Ferrier, W. J. (2001). Navigating the competitive landscape: The drivers and consequences of competitive aggressiveness. Academy of Management Journal, 44(4), 858-877.

FSSS. (2014b). Federal State Statistical Service. Russian Federation. Population by age groups. Retrieved from http://www.gks.ru/bgd/regl/b14 12/IssWWW.exe/stg/d01/05-02.htm

FSSS. (2015). Federal State Statistical Service. Russian Federation. Population. . Retrieved from http://www.gks.ru/bgd/regl/b14 12/IssWWW.exe/stg/d01/05-01.htm.

Gardels, N. (2014). Full Circle: From a Post-Cold War Peace to a World Splitting into Blocs. New Perspectives Quarterly, 31(4), 2-4. doi:10.1111/npqu.11479

Ghauri, P. (2004). Designing and conducting case studies in international business research. Handbook of qualitative research methods for international business, 109-124.

Ghauri, P. N., \& Grønhaug, K. (2005). Research methods in business studies: A practical guide: Pearson Education.

Hague, W. (2014). Oral statement to Parliament: Russia's actions in Crimea. Retrieved from https://www.gov.uk/government/speeches/russias-actions-in-crimea.

Jennings, G. (2015). Russian An-140 production halted by Ukrainian sanctions. . London - IHS Jane's Defence Weekly.

Kogut, B. (1991). Country capabilities and the permeability of borders. Strategic Management Journal, 12(S1), 33-47.

KUCHMA. (2014, April 13, 2014) Ex-President Kuchma Says Only West Can Resolve Ukraine Crisis. Radio Free Europe.

Larson, D. W., \& Shevchenko, A. (2014). Russia says no: Power, status, and emotions in foreign policy. Communist and post-communist studies, 47(3), 269-279.

Lee, J.-W., Song, H. S., \& Kwak, J. (2014). Internationalization of Korean banks during crises: The network view of learning and commitment. International Business Review, 23(6), 1040-1048.

Lee, T. W., Mitchell, T. R., \& Sablynski, C. J. (1999). Qualitative research in organizational and vocational psychology, 1979-1999. Journal of vocational behavior, 55(2), 161-187.

Levy, J. S. (2008). Case studies: Types, designs, and logics of inference. Conflict Management and Peace Science, 25(1), 1-18.

Lugar, R. (2005). Lugar and Obama Urge Destruction of Conventional Weapons Stockpiles. Retrieved from http://www.fas.org/asmp/campaigns/MANPADS/2005/LugarObama.htm

Mankoff, J. (2014). The Russian Economic Crisis: Council on Foreign Relations.

McFaul, M., Sestanovich, S., \& Mearsheimer, J. J. (2014). Faulty Powers: Who Started the Ukraine Crisis. Foreign Aff., 93, 167.

McFaul, M. A. (2014). confronting putin's russia. The New York Times, 23.

McLees, A., \& Rumer, E. (2014). Saving Ukraine's Defense Industry. . Retrieved from http:/ / carnegie.ru/publications/?lang $=$ en\&fa $=56282$

Mearsheimer, J. J. (2014). Why the Ukraine Crisis is the West's Fault. Foreign Affairs, 93(5), 77-89.

NKMZ. (2014). NKMZ Novokramatorsky Mashinostroitelny Zavod website. Retrieved from http:/ / www.nkmz.com/index.php?id=2\&L=1

Pressman, J. L., \& Wildavsky, A. B. (1973). Implementation: How Grert Expectations in Washington are Dashed in Oakland; Or, why It's Amazing that Federal Programs Work at All: University of California Press.

Putin. (2014). Direct Line with Vladimir Putin. Retrieved from http://eng.news.kremlin.ru/news/7034/print

Reuveny, R., \& Barbieri, K. (2014). On the effect of natural resources on interstate war. Progress in Physical Geography, 38(6), 786-806.

Rogozin, D. (2013, 17/12) Deputy Prime Minister and Chairman of the Military-Industrial Commission, Russian Federation. "Echo of Moscow" Radio interview transcript. Translated with the aid of Google Translate./Interviewer: N/A. Moscow.

Rutland, P. (2014). The impact of sanctions on Russia. Russian Analytical Digest, 157, 2-8.

Simha, R. (2014). Satan scare: Why the US is going ballistic over a Russian missile. . Retrieved from http://in.rbth.com/blogs/2014/05/23/satan scare why the us is going ballistic over a russian missile 35461

Smith, P. (2015). The New York Times' basically rewrites whatever the Kiev authorities say': Stephen F. Cohen on the US/Russia/Ukraine History the Media Won't Tell You. Salon, April, 16. 
Snyder, T. (2014). Fascism, Russia, and Ukraine. The New York Review of Books, 20.

Sutyagin, I., Clarke, M., \& Eyal, J. (2014). Ukraine Crisis: The Strategic Importance of Slavyansk.

TASS. (2015a). 800,000 refugees from Ukraine's south-east stay in Russia. Retrieved from http://itartass.com/en/russia/772124

Tatsenko, L. (2014). Why Ukraine is reforming its higher education system. . Retrieved from http://www.britishcouncil.org/blog/why-ukraine-reforming-its-higher-education-system.

Tolip. (2007). Admiral Kuznetsov the only aircraft carrier in the Russian Navy. Retrieved from http://www.militaryheat.com/39/admiral-kuznetsov-aircraft-carrier-russian-navy/

Treisman, D. (2014). Putin's popularity since 2010: why did support for the Kremlin plunge, then stabilize? Post-Soviet Affairs, 30(5), 370-388.

Tsygankov, A. (2014). The sources of Russia's Ukraine policy. Russian Analytical Digest, 18(158), 3.

Tsygankov, A. (2015). Vladimir Putin's last stand: the sources of Russia's Ukraine policy. Post-Soviet Affairs, 31(4), 279303.

Ukrstat. (2014). Ukrstat: Population as of December 1, 2013. Average annual populations January-November 2013. Retrieved from Kiev Ukraine: http://ukrstat.org/en/operativ/operativ2013/ds/kn/kn e/kn1213 e.html

United-Nations. (2015). Russian Federation Population change per year (thousands).

Medium variant 2015-2050. . Retrieved from http://esa.un.org/unpd/wpp/unpp/p2k0data.asp

Yin, R. K. (1981). The case study crisis: Some answers. Administrative science quarterly, 26(1), 58-65. 